\title{
A study of the Agronomic parameters of Dominican Cattail (Typha domingensis) as influenced by type of fertilizer application.
}

\author{
Aderinola O.A and Adesina Idowu A.I \\ Department of Animal Production and Health, Ladoke Akintola University of Technology, PMB 4000 \\ Ogbomoso, Oyo State, Nigeria
}

\begin{abstract}
A study laid out in a randomized complete block design was used to determine the agronomic performance of Dominican cattail (Typha domingensis) as influenced by poultry manure and NPK 15:15:15 fertilizer application. The fertilizer was applied to supply 200kgN/ha. Data on plant height, number of tillers/ stand, number of leaves /tiller and biomass yield was collected at $4^{\text {th }}, 8^{\text {th }}$ and $12^{\text {th }}$ week of fertilizer application. Biomass yield was significantly $(P<0.05)$ affected by the type of fertilizer applied with the highest value recorded in NPK based plots at $4^{\text {th }}$ and $8^{\text {th }}$ week $(277 \mathrm{~g}$ and $1385.33 \mathrm{~g}$ respectively) but week 12 showed the highest value in poultry based plot(1802.00g). Plant height was observed to follow the same trend as biomass yield with the highest value observed in NPK based plot at eek 4 and $8(131.53$ and $182.93 \mathrm{~cm}$ respectively. However effects of type of fertilizer application were not observed on tiller numbers in this study. Cattail plant being a hydrophyte could thus be able to reduce the effect of forage scarcity during off season periods
\end{abstract}

\section{Introduction}

Forages are the main feed source for ruminant animals in meeting their nutritional needs (Aderinola et al., 2007); but varies in quality with season and location (Akingbade et al., 2009). Herbage yield during the rainy season is usually high, however it productivity declines sharply during the dry season, when leaves are dry and coarse with low feeding value (Aderinola et al., 2010). Sabiiti,(1992) reported that during dry season in humid and sub-humid zones of Nigeria and Uganda, the quality of grasses may decline up to 3\% crude protein(CP) which is below critical level of 7\% CP recommended by Minson,(1990). This limits intake and digestibility with subsequent low animal productivity.

In rangelands some part of the land might not be accessible during the periods of rains, they are swampy and water logged. However during the dry season these areas are usually available because of the reduced water level. These areas of land are usually grown with hydrophyte plant and some of these plants might be available for animal during the dry season when forages are usually scarce.

Cattail is an abundant emergent hydrophyte commonly found growing in dense stands in areas with shallow water or seasonal flooding, or as a narrow band along the margins of deeper water. It is a widespread plant, found throughout most of North America, Europe, Asia and Africa. They are tall stiff plants growing almost ten feet tall; their leaves look like giant blades of grass, about one-inch wide. It is a perennial plant of temperature requirement between $10-45^{\circ} \mathrm{C}$, rainfall requirement of $500-1300 \mathrm{~mm}$, soil depth of $0.15-0.5 \mathrm{~m}$, soil texture of either clay loamy, clay or a sandy soil and a soil $\mathrm{pH}$ of 6.0-7.3

Stevens and Hoag (2006) reported that; all parts of the cattail are edible when gathered at the appropriate stage of growth. Akingbade et al., (2006) reported that in pure stand of pasture grass, top dressing of nitrogen fertilizer gives significant increase in herbage dry matter yield, which also affects its agronomic parameter and availability to animals. Van Bury et al (1981) reported that usage of fertilizer nitrogen has enabled the benefits associated with the adoption of improved cultivation and development of intensively managed livestock systems

The aim of the research was thus to determine the effect of fertilizer types (N-P-K and poultry manure) on the agronomic performance of cattail plant in the derived savannah zone of Nigeria.

\section{Site of the experiment}

\section{Materials And Methods}

The experiment was carried out at Ladoke Akintola University of Technology Teaching and Research Farm, (Lautech), Ogbomoso, Nigeria. Ogbomoso is located at longitude $4^{`} 10^{`}$ and latitude $8^{`} 10^{`} \mathrm{~N}$ in derived savannah of South-western Nigeria (BATC 2005). 


\section{Land preparation}

Using a randomized complete block design an experimental site measuring $15 \mathrm{mx} 15 \mathrm{~m}$ was that is usually waterlogged in the rainy season and assessable during the dry season was used. The site was cleared and manually tilled before planting. After clearing, soil samples were randomly taken at $0-15 \mathrm{~cm}$ depth with the aid of soil auger and thoroughly mixed in a plastic basket to form a composite sample used for the soil analysis. Nine beds each with a dimension of $3 \mathrm{~m} \times 3 \mathrm{~m}$ and with $1 \mathrm{~m}$ space between beds was constructed. Two tillers of cattail cut to about $20 \mathrm{~cm}$ height, gotten from a drainage channel around the school were planted per stand at a spacing of $50 \mathrm{~cm} \times 50 \mathrm{~cm}$ inter and intra-row spacing. At harvest (after 12weeks of fertilizer application) another set of composite soil samples were taken as a representative of each treatment and analysed for the soil chemical as described by A.E.S (1998). The treatments include cattail fertilized with poultry manure (T1), cattail fertilized with N-P-K 15:15:15(T2) and unfertilized cattail stands (T3) which serves as the control. Each treatment was replicated thrice.

\section{Collection of manure}

Poultry manure, collected at the layers unit (battery cage) of the Teaching and Research farm was sundried until it is crispy, while the NPK 15:15:15 fertilizer was procured.

The fertilizers were applied two weeks after planting at the rate of $200 \mathrm{~kg} \mathrm{~N} / \mathrm{ha}$ using broadcasting method of fertilizer application. The quantity applied per plot for both poultry manure and N-P-K fertilizer are shown below:

Amount of fertilizer required $/$ plot $=\frac{\text { PLOT SIZE }}{10,000 \mathrm{~m}^{2}} \times \frac{\text { rate }}{\text { Conc }} \times 100$

Where:

The concentration of Nitrogen $(\mathrm{N})$ in poultry manure is $5 \% \mathrm{~N}$ and $15 \% \mathrm{~N}$ in N-P-K.

Plot size $=3 m \times 3 m=9 m^{2}$.

Thus;

$$
\begin{gathered}
=\frac{9 \mathrm{~m} 2}{10,000 \mathrm{~m}^{2}} \times \frac{200 \mathrm{kgN} / \mathrm{ha}}{5 \mathrm{~kg} / \mathrm{N}} \times \frac{100}{1} \\
\text { Total Quantity applied }=3.6 \mathrm{~kg} \times 3 \text { plots } \\
\text { Total Quantity applied }=10.8 \mathrm{~kg} \text { of poultry manure. }
\end{gathered}
$$

\section{Data collection}

Agronomic parameters collected at the $4^{\text {th }}$ week, $8^{\text {th }}$ week and $12^{\text {th }}$ week after fertilizer application; include the plant height, the number of tillers per stand, number of leaves/tiller, and the biomass yield. The plant height was measured randomly from each treatment with the aid of the measuring tape. The number of leaves and the tiller's number were counted while the biomass yield was determined by weighing the total plants within each replicate in a $1 \mathrm{~m}^{2}$ quadrat, done by cutting at about $20 \mathrm{~cm}$ above ground level.

\section{Statistical Analysis}

Data collected were analysed using of SAS statistical package and their means were separated using the Duncan multiple range F-test of the same statistical package.

\section{Results and Discussion}

Table 1 shows the results of the soil chemical composition before and after fertilizer application. The result of the soil analysis revealed that the fertilizers (organic and inorganic) were significant in the nutrient accumulation of the soil which may also influence the performance of the cattail plant.

The highest significant value for nitrogen was observed in NPK treated plots $(0.10 \mathrm{cmol} / \mathrm{kg})$ and the least value was of $0.05 \mathrm{cmolg} / \mathrm{kg}$ was observed in the control treatment. This could be due to the application of NPK, an inorganic source of fertilizer which will be easily released into the soil. The lower value observed in the control treatment even over the initial value could be due to uptake of soil nutrients from the soil. Application of NPK fertilizer and poultry manure also resulted into higher significant values of the $\mathrm{P}, \mathrm{K}, \mathrm{Mg}$ and $\mathrm{Ca}$ contents of the soil compared with the control and initial values. NPK contain P and $\mathrm{K}$ which will increase the concentration of available $\mathrm{P}$ and $\mathrm{K}$ in the soil. Poultry manure is also rich in $\mathrm{P}, \mathrm{K}$, and Ca. These will also increase the quantity of available $\mathrm{P}, \mathrm{K}$, and $\mathrm{Ca}$ in the soil. 
Table 2 shows the agronomic parameters of cattail as influenced by fertilizer application. It was observed that the biomass yield was significantly different from each other with the highest value observed in NPK based plots at week 4 and 8 (277g and 1385.33g respectively) but week 12 showed the highest value in poultry manure based plots. Newman et al., (1996), reported that Cattail exhibits exceptionally increased growth in response to nitrification. The higher values observed in week 12 may be due to late release of nutrient from the organic source. This agrees with the findings of Plaster (1992) that the release of any nutrient from organic fertilizer is gradual. However at this stage there would have been the leaching away of inorganic fertilizer. Available nitrogen is an effective stimulant to grass growth because it influences both leaf production and photosynthesis. The increase in yield due to fertilizer application could be attributed to increase in leaf production, improved plant height and photosynthesis.

Gastal et al (1992) reported that nitrogen greatly increases the rate of leaf extension but loosely related to the rate of leaf appearance. This rate of leaf extension then stimulates greater light capture and hence photosynthesis and thus increase yield. Fertilizers especially nitrogen, increases leaf size of grasses (Nelson 1992) leaf elongation rate and tillering (brown and Ashley 1974) these features lead to high yield of grasses. Sodehinde et al (2006) observed that nitrogen fertilizer influence positively the number of tillers produced per stand in an experiment on the effect of nitrogen on dry matter yield of Panicum maximum. However effect of fertilizer application was not observed on tillers number in this experiment. This might be due to the growth habit of cattail. Least values for biomass were observed in the control which however increases with age of the plant. The plant height was also observed to follow the same trend as the biomass yield with the highest value observed in NPK based plot at week 4 and 8 (131.53 and $182.93 \mathrm{~cm}$ respectively) however week 12 reported the highest plant height at poultry manure treated plots. Numbers of tillers per stand were observed to be similar between treatments and between weeks of harvest.

Cattail being a hydrophyte plant could thus make forages available to plants during the dry season when it will be easy for animals to graze and waterlogged areas. Further research work on it nutrient utilization is to be carried out.

\section{Conclusion}

The results of this study indicated that agronomic performance of cattail has a positive correlation with nutrient enrichment of the soil at all the three stages of harvest (fourth, eighth and twelfth week after fertilizer application). However, problem of high moisture at four weeks may reduce dry matter intake and palatability in animals.

Table 1: Soil chemical composition of the experimental field $(0-15 \mathrm{~cm})$

\begin{tabular}{llllll}
\hline Parameters & Before & After & & \\
\cline { 3 - 5 } & & Poultry manure & NPK & Control & SEM \\
\hline $\mathrm{N} \mathrm{cmol} / \mathrm{Kg}$ & $0.08^{\mathrm{b}}$ & $0.08^{\mathrm{b}}$ & $0.10^{\mathrm{a}}$ & $0.05^{\mathrm{c}}$ & 0.003 \\
$\mathrm{P} \mathrm{cmol} / \mathrm{Kg}$ & $13.56^{\mathrm{d}}$ & $14.52^{\mathrm{a}}$ & $14.38^{\mathrm{b}}$ & $13.91^{\mathrm{c}}$ & 0.800 \\
$\mathrm{~K} \mathrm{cmol} / \mathrm{Kg}$ & $0.59^{\mathrm{c}}$ & $0.75 \mathrm{~b}$ & $0.84 \mathrm{a}$ & $0.56 \mathrm{~d}$ & 0.024 \\
$\mathrm{Mg} \mathrm{mg} / \mathrm{Kg}$ & $1.61^{\mathrm{a}}$ & $0.70^{\mathrm{c}}$ & $0.73^{\mathrm{b}}$ & $0.69^{\mathrm{c}}$ & 0.082 \\
$\mathrm{Ca} \mathrm{mg} / \mathrm{Kg}$ & $2.39^{\mathrm{c}}$ & $2.43^{\mathrm{b}}$ & $2.48^{\mathrm{a}}$ & $2.40^{\mathrm{c}}$ & 0.007 \\
$\mathrm{OC} \mathrm{mg} / \mathrm{Kg}$ & $1.72^{\mathrm{c}}$ & $1.96^{\mathrm{b}}$ & $1.98^{\mathrm{a}}$ & $1.53^{\mathrm{d}}$ & 0.039 \\
$\mathrm{pH} \mathrm{mg} / \mathrm{Kg}$ & $6.01^{\mathrm{b}}$ & $5.90^{\mathrm{b}}$ & $5.04^{\mathrm{c}}$ & $6.10^{\mathrm{a}}$ & 0.085 \\
\hline
\end{tabular}

${ }^{\text {abcd }}$ Means with different superscripts on the same row are significant $(\mathrm{p}<0.05)$

Table 2: Agronomic parameters of Cat tail as influenced by type of fertilizer application at various weeks

\begin{tabular}{|c|c|c|c|c|}
\hline parameters & $\begin{array}{l}\text { Poultry manure } \\
1\end{array}$ & $\begin{array}{l}\text { NPK } \\
2\end{array}$ & $\begin{array}{l}\text { Control } \\
3\end{array}$ & SEM \\
\hline \multicolumn{5}{|c|}{$\begin{array}{l}\text { At } 4 \text { week after fertilizer } \\
\text { application }\end{array}$} \\
\hline Biomass & $127.00^{\mathrm{b}}$ & $277.00^{\mathrm{a}}$ & $107.00^{\mathrm{c}}$ & 18.40 \\
\hline Tiller/stand & 2.33 & 2.53 & 2.33 & 0.199 \\
\hline Plant height $(\mathrm{cm})$ & $129.53^{\mathrm{b}}$ & $131.53^{\mathrm{a}}$ & $121.42^{\mathrm{c}}$ & 1.079 \\
\hline No of leaves/tillers & $9.60^{\mathrm{b}}$ & $11.40^{\mathrm{a}}$ & $9.60^{\mathrm{b}}$ & 0.286 \\
\hline \multicolumn{5}{|l|}{ At 8 weeks } \\
\hline Biomass & $1102.87^{b}$ & $1385.33^{\mathrm{a}}$ & $793.33^{c}$ & 58.64 \\
\hline Tiller/stand & 2.47 & 2.74 & 2.33 & 0.202 \\
\hline Plant height $(\mathrm{cm})$ & $155.33^{\mathrm{c}}$ & $182.93^{\mathrm{a}}$ & $157.47^{\mathrm{b}}$ & 3.047 \\
\hline No of leaves/tillers & $11.40^{\mathrm{a}}$ & $11.53^{\mathrm{a}}$ & $9.80^{\mathrm{b}}$ & 0.275 \\
\hline \multicolumn{5}{|l|}{ At 12 weeks } \\
\hline Biomass & $1922.00^{\mathrm{a}}$ & $1802.00^{\mathrm{b}}$ & $1552.00^{\mathrm{c}}$ & 37.38 \\
\hline Tiller/stand & 2.98 & 2.80 & 2.74 & 0.199 \\
\hline Plant height $(\mathrm{cm})$ & $188.55^{\mathrm{a}}$ & $179.93^{\mathrm{b}}$ & $167.11^{\mathrm{c}}$ & 2.146 \\
\hline No of leaves/tillers & 11.73 & 11.57 & 10.67 & 0.228 \\
\hline
\end{tabular}


a,b,c Means with different superscripts on the same row are significant $(\mathrm{p}<0.05)$

$\mathrm{T}_{1}=$ cattail + poultry manure at $200 \mathrm{~kg} \mathrm{~N} \mathrm{ha}^{-1}$.

$\mathrm{T}_{2}=$ cattail + NPK 15:15:15 at $200 \mathrm{kgN} \mathrm{ha}^{-1}$.

\section{References}

[1]. Aderinola, O.A, Akinlade, J. A., Akingbade A.A and Asaolu, V.A. (2010), Proximate composition of Andropogon tectorum as influenced by varied inter row spacing of Lablab purpureus during a minor wet season in the derived savannah zone of Nigeria, Proceeding of the 44th Annual Conference of Agricultural Society of Nigeria, 18-22 October, Ladoke Akintola University of Technology, Ogbomoso, Nigeria. pp 733-736.

[2]. Aderinola, O.A, Akinlade, J.A., Akingbade, A.A, Rafiu, A., Olabanji, R.O. and Akinwumi, A.O. (2007). Agronomic performance of Andropogon tectorum planted with varying inter-sown spacing of Stylosanthes hamata during a water stress period. Proceeding of 32nd Annual Conference of Nigeria society of Animal Production, 18-21 March, University of Calabar, Calabar, Cross-river state, Nigeria. pp 210-212.

[3]. AES (1998) agricultural Experimental Station of North Central Region of America.

[4]. Akingbade, A.A., Aderinola, O.A. and Asaolu, V.O. (2009). Forage management. Amstrong Plus Commmunications, 48, Nitel Road, Takie, Ogbomoso. pp 85. ISBN: 978-2902-08-2.

[5]. Akingbade, A.A, Akinlade, J.A. and Aderinola, O.A. (2006), Basic concepts in pasture science, Positive press, Opposite Union Bank, Iwo Road, Ibadan, Nigeria. pp 84. ISBN: 978-37813-8-3

[6]. BATC (2005). British American Tobacco Company, Metrological site Ogbomoso, Nigeria.

[7]. Brown, R.H and D.A. Ashley(1974). Fertilizer effect on photosynthesis ,organic reserves and regrowth mechanism of forages. In. D.A. May. (Ed). Forage fertilization. ASA, Madison, W.I. pp 455-479.

[8]. Gastal. F., G. Belanger and G. Lamaire (1992). A model of the leaf extension rate of tall fescue in response to nitrogen and temperature. Annals of Botany. 70. 347

[9]. Minson, D J. (1990). Calcium in forage. In. Forage in ruminant nutrition. Academic Press Inc. San DiegoNelson, C.J.(1992). Physiology of leaf growth in grasses. In. Proc. $14^{\text {th }}$ General meeting of European grassland federation. Lahti, Finland. $8^{\text {th }}-11^{\text {th }}$ June . 1992. Pp 175-179.

[10]. Newman, S., J. B. Grace, and J. W. Koebel. (1996). Effects of nutrients and hydroperiod on Typha, Cladium, and Eleocharis: Implications for Everglades restoration. Ecological Applications 6:774-783.

[11]. Plaster, E.J. (1992). Soil science management (2nd Edition). Delme Publishers. pp 321.

[12]. Sabiiti, E.N. (1992). Fodder development in the humid and sub-humid zones of Nigeria and Uganda. Lecture present at FAO regional training workshop in management of pastures in East Africa. Egerton University 6-7 August, 1990.

[13]. Sodehinde, F.G., Asaolu, V.O., Adeleye, I.O.A., Adewumi, M.K. Oyebanji B. and Adeniyi, S.A.(2006). Effect of nitrogen fertilizer on the dry matter productivity of Panicum maximum and soil copper and manganese contents in the derived savanna zone of Nigeria. Proc. Of the $31^{\text {st }}$ Annual conf. of Nigeria society for Animal Production. $12^{\text {th }}-15^{\text {th }}$ March, 2006. Bayero University, Kano. Nigeria.

[14]. Stevens, M., Hoag, C., (2006). Southern cattail (Typha domingensis Pers.). United State Department of Agriculture (USDA), National Resources Conservation Service, Plant Material Center,Aberdeen, Idaho, U.S.A. Plant guide. pp 4.

[15]. Van Bury P.F.J., Prins, W.H., Den Boer, D.F and Sluiman, W.J. (1981). Nitrogen and intensification of livestock farming in EEC countries. Proceedings of the fertilizers society. No. 1999. 